\title{
Black Bears, Palms, and Giant Palm Weevils: An Intraguild Mutualism
}

\author{
D. Shane Tedder ${ }^{1}$, John J. Cox ${ }^{*}, 1$, Philip H. Crowley ${ }^{2}$ and David S. Maehr ${ }^{1, \dagger}$ \\ ${ }^{I}$ Department of Forestry, University of Kentucky, Lexington, KY 40506, USA \\ ${ }^{2}$ Department of Biology and Center for Ecology, Evolution and Behavior, University of Kentucky, Lexington, KY 40506, \\ USA
}

\begin{abstract}
In peninsular Florida, USA, the palm-feeding guild is dominated by the black bear (Ursus americanus floridanus, Pallas) and the giant palm weevil (Rhynchophorus cruentatus, Fabricius). Bears damage palms by consuming their hearts, allowing the weevil to reproduce within the exposed palm tissue. The giant palm weevil reproductively benefits from bear-damaged palms, and bears gain a valuable fat-rich food supply from consuming the insects, an apparent intraguild mutualism. We analyzed a natural experiment across widely distributed sites based on presence or absence of bear populations to test the hypothesis that the presence of bears increases the abundance of the giant palm weevil. Results support the hypothesis; data also show greater attraction of females than males to pheromone traps and indicate a predominance of activity by the insect during the day and at lower summer temperatures. This interaction closely resembles one previously documented involving indigenous humans in Amazonia.
\end{abstract}

Keywords: Community, ecology, Florida, omnivory, pheromones, predation, subtropical.

\section{INTRODUCTION}

Omnivory complicates ecological relationships (e.g. see Pimm and Lawton 1978, Bruno and Connor 2005). By consumption at two or more different trophic levels, consumers enhance the potential for indirect and trait-mediated effects with important implications at population and community levels. The intraguild predation (IGP) framework and the empirical and theoretical advances associated with IGP have enriched our understanding of these effects and their implications (Holt and Polis 1997, Rosenheim 2007 and associated articles in a special issue). Moreover, IGP can be closely associated with intraguild mutualism (IGM), mutual facilitation within guilds (Crowley and Cox 2011). Consider the following entomophagical example.

Insect larvae figure prominently in the diets of indigenous humans in several tribes of Venezuelan and Columbian Amazonia (Bodenheimer 1951, Defoliart 1995, Dufour 1987, Choo et al. 2009). Men from villages fell some species of palm trees (e.g. Oenocarpus bacaba, Martius) to harvest the fruit and return later to obtain "palm grubs", larvae of the palm weevil Rhynchophorus spp., that invade the pith following felling (Dufour 1987). Among Tukanoans, these larvae are considered a delicacy, containing more than $50 \%$ fat and about $25 \%$ protein, with roughly the dietary composition of pork sausage (Dufour 1987). This nutritional contribution to the fat-limited diet of the Indians can be important (Dufour 1987), and the opportunities for feeding and reproduction afforded the insects by this cultivation process clearly benefits them as well.

*Address correspondence to this author at the Department of Forestry, University of Kentucky, Lexington, KY 40506, USA; Tel: (859) 257-9507; Fax: (859) 323-1031; E-mail: jjcox@uky.edu

${ }^{\dagger}$ Deceased
During field work in southern Florida, we noticed an apparently similar interaction among the giant palm weevil (GPW) (Rhynchophorus cruentatus, Fabricius), palms (particularly cabbage palm, Sabal palmetto, Loddiges, but occasionally saw palmetto, Sabal repeans, Bartram), and the black bear (Ursus americanus floridanus, Pallas) in which the bears seemed to be taking the role of the Indians in the Amazonian example. The widespread palm habitat in the sub-tropics of the southeastern USA and the patchy distribution of black bear populations provided the opportunity to analyze a natural experiment testing a prediction linked to the IGM hypothesis. If the GPW benefits at the population scale from its interaction with the black bear, then weevils should live at higher densities in habitats with black bear populations relative to those without them. In the remainder of this article, we describe the natural history of the Florida study system, summarize the methods of analysis and statistical evaluation, present results, and place our findings in the context of the literature and the emerging conceptual framework.

\section{Natural History of the System}

Although most true weevils average $<10 \mathrm{~mm}$ in length (Foltz 2001), adult GPWs measure 2-3 cm and are the largest weevil in North America (Weissling et al. 1993). The GPW ranges from the Florida Keys through palm-inhabited portions of the southeast coastal plain of the United States (Wattanpongsiri 1966). The GPW is a habitat specialist and depends on damaged palm tissue for food and breeding habitat (Weissling et al. 1993). This insect has been present in Florida for more than $1 \mathrm{M}$ years (Weissling and GiblinDavis 1997) and co-evolved with the diverse palm flora and post-Pliocene megaherbivores of the sub-tropical US ecoregion. Although the GPW is sympatric with the native cabbage palm in Florida (Woodruff 1967), the weevil can also complete its life cycle on damaged saw palmettos and 
other palm species (Stevenson 1996, Hunsberger et al. 2000). Palms that are stressed or damaged (typically in the crown or stem) emit volatile compounds that attract adult GPW (Weissling et al. 1992, 1993). When a male weevil finds a suitably damaged palm, it releases an aggregation pheromone that interacts synergistically with the palm's volatile compounds to attract other weevils (Weissling et al. 1993, Giblin-Davis et al. 1996). This aspect of the GPW's chemical ecology was first recognized in 1928, when an entomologist observed weevils attracted to freshly painted automobiles in Sanford, Florida (Bare 1929). The chemical ecology of GPWs has received significant attention because of its potential role as a vector of the red ring nematode (Bursaphelenchus cocphilus, Cobb (Baujard)) (Weissling et al. 1992) that causes lethal red ring disease of coconut ( $\mathrm{Co}-$ cos nucifera, Linneaus) and African oil palm (Elaeis guineensis, Jacquin) (Giblin-Davis et al. 1994). The GPW ingests or inadvertently transports the nematode from infected palms to other damaged palms (Brammer and Crow 2001). The nematode quickly invades the leaves, stem, and roots of infected palms, with death often rapid from blockage of vascular tissue. The palm management-driven investigation of the GPW led to the discovery of its synthetic aggregation pheromone, 5-methyl-4 octanol, or cruentol (Weissling et al. 1994). As the weevils aggregate they consume palm apical meristem tissues and breed; each female may then deposit more than 200 eggs directly onto the damaged tissue or in the petiolar bases of the leaves (Weissling and Giblin-Davis 1994, Hunsberger et al. 2000). The eggs hatch within 64 hours, and the larvae consume buds and leaf sheaths of the palm (Weissling and Giblin-Davis 1997, Hunsberger et al. 2000). Larvae can grow to $4 \mathrm{~cm}$ in length before they migrate to the petioles of the trees to prepare cocoons from palm fibers. The larvae enter a pre-pupal and then a pupal stage before emerging from cocoons several weeks later. This entire process, from egg to adult, takes approximately 84 days (Weissling and Giblin-Davis 1997).

Cabbage palm and saw palmetto are found throughout the sub-tropical southeastern USA (Gilman and Watson 1994). Saw palmetto is the most abundant palm species in the USA, reaching its peak densities in Florida (Maehr and Layne 1996). The cabbage palms frequently die after black bears consume the apical meristems (Oliveria et al. 1989, Hunsberger et al. 2000), but saw palmetto sprouts new growth, increases flowering and reproduces vegetatively (Maehr and Layne 1996, Abrahamson 1999).

The black bear is a habitat generalist that inhabited most of North America and virtually all of Florida prior to European colonization (Brady and Maehr 1985) and is therefore sympatric with several palms species in the southeastern U. S. Habitat loss, fragmentation and overexploitation have reduced the bear's distribution in Florida to approximately $18 \%$ of its historic range, with remaining individuals largely confined to 7 disjunct populations scattered throughout the state (Florida Fish and Wildlife Conservation Commission 2010). As a result, the black bear is listed as a threatened species in Florida (Florida Fish and Wildlife Conservation Commission 2010).

Where it persists, the black bear frequently consumes the fiber and fruit of saw palmetto and cabbage palm (Maehr and
DeFazio 1985, Maehr et al. 2001). The predilection to remove and consume the apical meristems from palms creates the damage and stress necessary for feeding, breeding, and larval development of the giant palm weevil (Fig. 1). We have observed that when a black bear consumes

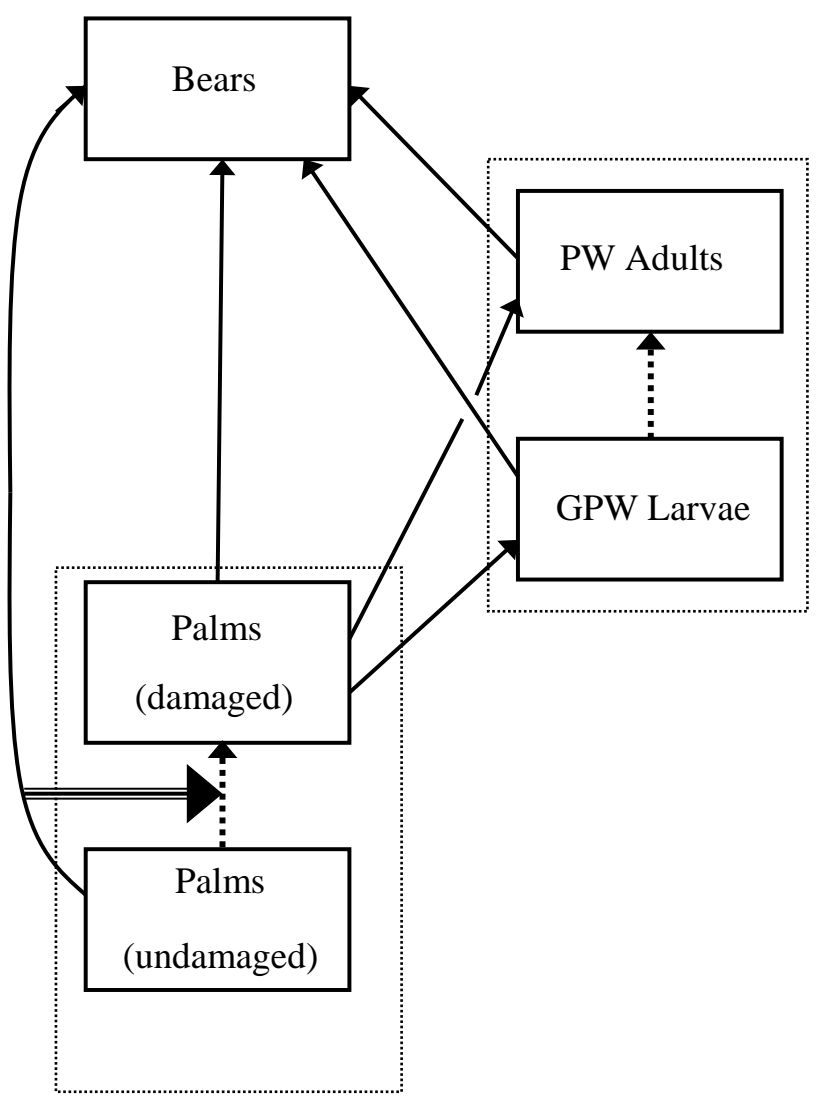

Fig. (1). Interactions among black bears, palms, and giant palm weevils (GPW) in Florida at sites where bears are present. Solid arrows indicate consumption, dotted arrows are within-species transitions, and the striped arrow indicates that feeding by bears on initially undamaged palms produces damage and makes them available for utilization by GPW.

the heart of a cabbage palm or saw palmetto, volatile compounds released by the damaged palm rapidly attract adult GPW, which then mate and oviposit, resulting in larval development, pupation, and ultimately adult dispersal. Black bears consume both adult weevils and their larvae (Ulrey 2008) suggesting that damaged palms are revisited by bears after the initial feeding bout occurs, or that they happen on the larvae when seeking a meal of palm heart. The adult and larval GPW are among many food items that black bears consume in Florida (Maehr and Defazio 1985) but may contribute disproportionately to the bear's diet by being the most fat-rich food items that the bears consume (Oliveria et al. 1976; c.f. the case of the Amazonian Indians described above). As such, this mutualistic relationship may favor the more specialized habitat requirements of the weevil given that the habitat generalist black bear may damage palms that attract GPW, but never return to these damaged trees because it either cannot locate them, or because of the seasonal availability of more abundant or higher energy foods. 
In addition to attack by black bears, other factors may damage or stress palms enough to make them susceptible to infestation by the GPW (Giblin-Davis and Howard 1989). Fire is often used in management of public lands in Florida; frequent burning may be sufficient to allow colonization by the weevils (Abrahamson 1999). The cabbage palm is widely used in the landscaping industry in Florida (Godfrey 1988), and the associated transplanting may stress the plants. Other potential causes of stress and damage for palms include hurricanes, lightning strikes, flooding, logging, mowing to counteract years of fire suppression, and roller chopping to reduce the height of saw palmetto stands (see McPherson and Williams 1998).

\section{METHODS}

Research for this study was conducted at 6 natural areas in south and central peninsular Florida in the summer of 2005 and 2006 (Fig. 2, Table 1). These sites were chosen because of accessibility, and our fieldwork observations indicating relatively similar climate and plant communities with abundant populations of saw palmetto and cabbage palm; three of the sites supported resident black bear populations and three did not (Fig. 2). The presence of bears during our study period was determined by the presence of tracks and scat. Because one study site (Kissimmee Prairie Preserve) used in 2005 was discovered to have had a management regime that could have strongly influenced GPW abundance, it was dropped from the study and an additional site without resident bears (Highlands Hammock State Park) was added in 2006. Trapping was repeated at the Smoak Ranch in 2006 as a preliminary evaluation of annual variability in weevil populations.

At each site, 10 lethal bucket traps were used to capture GPW adults. The traps were constructed using 18.9 L (5 gal.) buckets topped with baffles made from ninety-six $5 \mathrm{~cm}$ sections of polyvinyl chloride pipe with an inside diameter of $2.4 \mathrm{~cm}$, connected using rubber cement (Weissling et al.

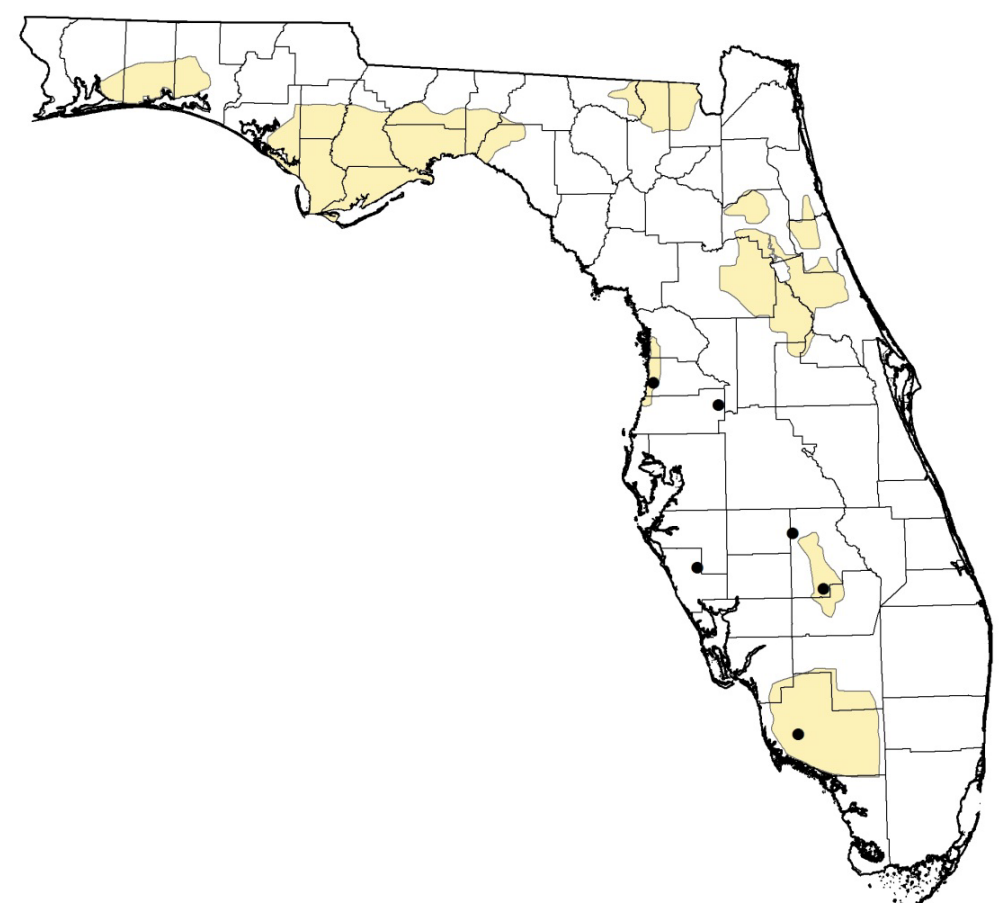

Fig. (2). Giant palm weevil trap sites in relation to primary black bear range (shaded) in Florida.

Table 1. Number of Giant Palm Weevils Captured and Mean Environmental Conditions Over 5-Day Consecutive Trap Intervals in Summers 2005-06, South Central Florida, USA

\begin{tabular}{|c|c|c|c|c|c|c|c|c|c|c|c|}
\hline \multirow[b]{2}{*}{ Trapping Location } & \multirow[b]{2}{*}{ Bears $^{a}$} & \multicolumn{2}{|c|}{ Sex } & \multicolumn{2}{|c|}{ Period } & \multirow[b]{2}{*}{ Total } & \multirow[b]{2}{*}{ Daily Mean } & \multirow[b]{2}{*}{ SE } & \multicolumn{2}{|c|}{ Temp. $\left(C^{o}\right)$} & \multirow[b]{2}{*}{ Total Precipitation (cm) } \\
\hline & & $\mathbf{F}$ & $\mathbf{M}$ & $\mathbf{A M}$ & PM & & & & Min & Max & \\
\hline Smoak Ranch $^{\mathrm{b}}$ (Highlands County) & Yes & 75 & 27 & 4 & 98 & 102 & 15.5 & 3.2 & 21.6 & 31.2 & 1.0 \\
\hline Weekiwachee Preserve & Yes & 39 & 6 & 0 & 45 & 45 & 9.0 & 1.9 & 20.8 & 32.0 & 1.5 \\
\hline Picayune State Forest & Yes & 45 & 13 & 5 & 53 & 58 & 11.6 & 7.1 & 24.0 & 34.3 & 1.9 \\
\hline Green Swamp West & No & 21 & 5 & 4 & 22 & 26 & 5.2 & 1.4 & 23.9 & 33.8 & 0.4 \\
\hline Highlands Hammock State Park & No & 22 & 6 & 6 & 19 & 28 & 5.6 & 1.0 & 21.6 & 35.7 & 0.2 \\
\hline
\end{tabular}

${ }^{\mathrm{a}}$ Resident bear occupancy

${ }^{\mathrm{b}}$ Averaged across 2005and 2006 


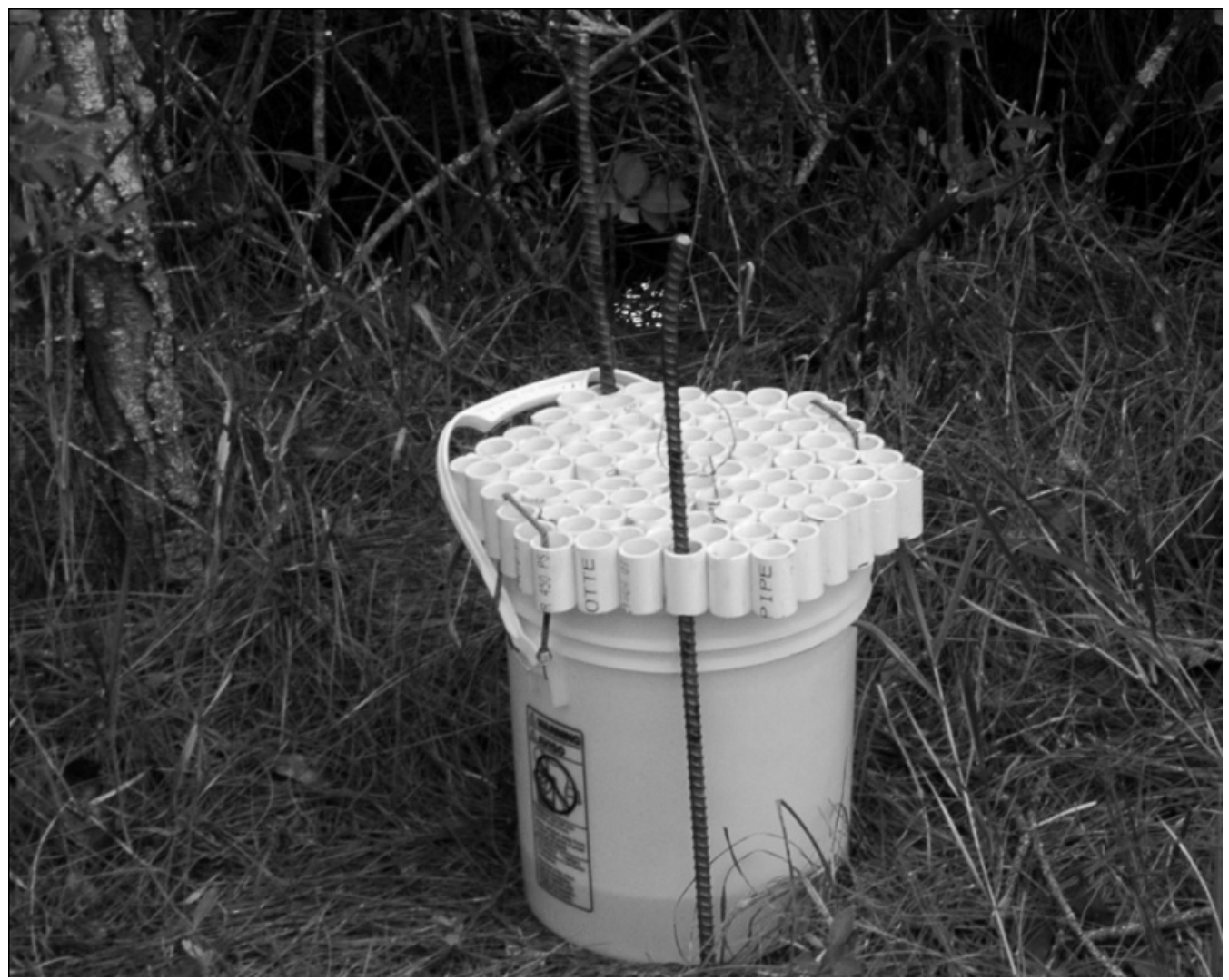

Fig. (3). A baffled-lid weevil trap secured with steel rebar at a collecting site.

1992; Fig. 3). Traps were baited with Cruentol ${ }^{\circledR}$ (Chemtica International, Costa Rica), a synthetic aggregation pheromone, and Weevil Magnet ${ }^{\circledR}$ (Chemtica International, Costa Rica) to simulate the volatiles produced by damaged or stressed palm tissue (Giblin-Davis et al. 1994). Each bucket was filled with $4.7 \mathrm{~L}$ (1 gal.) of water mixed with dishwashing detergent to quickly drown weevils caught in the trap. Two 75.6 (30 in.) sections of $1.3 \mathrm{~cm}$ (0.5 in.) steel rebar were used to secure the baffled lid to the trap by inserting the rebar through two outside pieces of the lid and into the ground (Fig. 3).

Twenty potential trap points were identified and plotted using a handheld GPS unit at each of the study sites during initial surveys. We chose points that were representative of the habitat and similar enough across sites that any differences in weevil densities would be more readily attributable to the presence or absence of the black bear. Each potential trap site was located $\geq 1 \mathrm{~km}$ from all others within the site and had $50-100 \%$ canopy cover that included both cabbage palm and saw palmetto. A random numbers table was used to choose 10 of these points at each site for weevil trap placement. Traps were randomly placed at each site within $25 \mathrm{~m}$ of the chosen GPS location and where both saw palmetto and cabbage palm were visible. At natural areas with resident bears, traps were located where damaged palms were not immediately visible, although bear-damaged palms did occur at other locations at these natural areas. Traps at 5 study sites were checked twice daily between 0700-1000 and 1700-2000 for 5 consecutive days from 5-June-2005 thru 18July-2005, and for Highlands Hammock State Park and for a second year at the Smoak Ranch, 14-July-2006 thru 18-July-
2006. All captured weevils were removed, sexed and preserved in glass jars containing denatured alcohol. Daily maximum and minimum temperatures and total daily precipitation were recorded for trapping days.

We used two approaches to test the hypothesis that higher weevil abundances and thus higher capture rates would be observed in areas occupied by bears than in areas where they were absent. One approach was based directly on the predicted pattern of relative magnitudes using a binomial exact randomization test. The logic is as follows. For this data set there are 720 different possible orderings of weevil abundances (highest to lowest) across the six sites (six factorial $=6 !=720$ ) but only 36 of these possible orderings have consistently higher weevil abundances in the presence of bears and lower abundances in the absence of bears $(3 ! 3$ ! $=36$ ). This means that the predicted pattern has a $5 \%$ probability of arising by chance alone $(=(36 / 720) \times 100 \%)$, providing the basis for our statistical test (see Manly 1991 and Crowley 1992). The other approach used was a t-test of the difference in mean weevil abundances for sites with bears present versus absent. For both of these tests we averaged the two weevil abundances obtained in different years at the Smoak Ranch to represent that site.

We used a zero-inflated negative binomial regression model and a negative binomial regression model to examine whether precipitation and temperature, respectively, were related to weevil trapping success. We also used paired ttests to evaluate site differences in weevil sex ratio and in capture success in the morning versus evening. Overall tests of sex ratio bias and of time-of-day bias were conducted using G-tests. 


\section{RESULTS}

As predicted, more GPW adults were trapped at sites containing bears (mean daily number captured and standard error $=12.0 \pm 1.9)$ than at sites without bears $(6.3 \pm 0.9)(\mathrm{p}=$ 0.05 by the binomial exact randomization test; and for the ttest, $\mathrm{p}=0.035, \mathrm{t}=3.14, \mathrm{df}=4)$ (Table 1). Although precipitation $(\mathrm{p}=0.200)$ and minimum daily temperature $(\mathrm{p}=$ 0.502 ) were not predictors of weevil capture success, maximum daily temperature $(\mathrm{p}<0.001)$ and average daily temperature $(\mathrm{p}=0.008)$ were; weevil capture success tended to be higher on cooler days. Nearly twice as many weevils were captured in $2005(n=102)$ than $2006(n=53)$ at the Smoak Ranch, which suggested the potential for substantial annual variability in GPW numbers. The capture data suggested that female GPW were more strongly attracted to the pheromonal signals emitted by the traps than were males (mean captures per day by sex across sites and standard error, males $=2.1 \pm$ 0.7 and females $=7.8 \pm 1.6 ; \mathrm{p}=0.002, \mathrm{t}=-5.77, \mathrm{df}=5$ ), and sites did not differ significantly in the extent of bias $\mathrm{X}^{2}{ }_{0.05}=$ 0.78 , df $=5$ ) (Table 1). About $90 \%$ of all of the GPW collected were found during the evening trap check, significantly more than in the morning (mean captures per sample by time of day across sites and standard error, morning samples $=1.02 \pm 0.23$ and evening samples $=9.06$ $\pm 2.32 ; \mathrm{p}=0.021, \mathrm{t}=-3.33, \mathrm{df}=5)$, and sites did not differ significantly in the extent of bias $\mathrm{X}^{2}{ }_{0.05}=4.04, \mathrm{df}=5$ ).

\section{DISCUSSION}

Based on pheromone trapping within and between sites differing in presence or absence of black bear populations, we have shown that GPW adults are more abundant in areas occupied by resident bears. This result supports a prediction arising from the hypothesis that the black bear-GPW interaction in peninsular Florida is an intraguild mutualism. A quantitative analysis of sources of palm damage (where this can be adequately established) that are associated with developing GPW broods could strengthen inference about the dependence of GPW on bears. If bears eventually extend or contract their range with respect to the sites sampled here, predicted shifts in GPW abundance could be tested.

Also consistent with this IGM hypothesis are published observations about the frequency and high nutritional value of GPW in bear diets (Maehr and Defazio 1985, Ulrey 2008). Additional studies of bear scat or especially of bear foraging behavior and energy budgets could further clarify the potential benefit of GPW consumption to bears. Of particular interest is whether bears return to palms that they or other bears have previously damaged to feed on GPW, as Tukanoan Indians do (Dufour 1987), or whether there are higher frequencies of use of damaged palms during certain times of the year. Camera trap studies using marked bears may indicate whether individuals tend to return to previously attacked palms after an interval long enough for the damaged trees to contain GPW larvae. In addition, the use of GPS collars with high fix intervals may provide a high enough resolution of location data to determine microhabitat use, particularly where palms are less frequent and visitation to individual trees might be more apparent during data analysis. By altering the appearance or odors produced by palms, it may be possible to simulate a previous bear attack and determine whether this attracts or repels bears during foraging. Note that even if bears are able to efficiently cultivate and exploit GPW, it seems certain that the bears have a strongly facilitative effect on GPW, much as forest regeneration is facilitated by gray squirrels (Sciurus carolinensis Gmelin) that do not retrieve each cached acorn (Quercus spp.) or hickory nut (Carya spp.) Jacobs and Liman 1991, Goheen and Swihart 2003).

Our understanding of mutualism has now moved well beyond the assumption that mutualisms occur primarily between a single pair of interacting species (Tscharntke and Hawkins 2002, Stanton 2003). While mutualisms involving insect and plant systems have received much attention (Weis and Abrahamson 1985, Gómez and Zamora 1994), similar relationships involving plants, insects and mammals remain under-studied (but see Janzen and Martin 1982, Sipura 1999, and Palmer et al. 2008). The relatively recent focus on intraguild relationships provides a superior framework for understanding the impact that consumption-mediated (effects of one species on another mediated by the consumption of biomass) and trait-mediated (effects of one species on another mediated by the traits of individuals or groups within one or both species) interactions among multiple species have on the distribution, abundance and evolution of the species involved (Crowley and Cox 2011). Much of this work to date has focused on intraguild predation (Rosenheim 2007), but intraguild mutualism (Crowley and Cox 2011) and related facilitative interactions are now more widely appreciated (Bruno et al. 2003, Blaustein and Chase 2007).

Since the GPW has been in Florida for a very long time (Weissling and Giblin-Davis 1997), it is useful to consider possible past interactions of GPW with the extinct suite of megafauna that existed in the region during the Pleistocene. Large herbivores such as the giant ground sloth (Megatherium), glyptodont (Glyptodon), and gomphothere (Haplomastodon) were all present in the sub-tropical and tropical regions of North America (Webb 1974, Janzen and Martin 1982) and potentially consumed the carbohydraterich apical meristems of the palms. The loss of these megaherbivores 10,000 years ago may have led to both a stronger dependence of GPW on black bear palm predation and relaxation of competition for the nutritious GPW. We suggest that the GPW may benefit more than the bears in this IGM, particularly in areas where alternative sources of palm disturbance are less frequent than that available in the disturbance-prone peninsular region of Florida. While the omnivorous bear has been observed to benefit from this relationship during fall hyperphagy (Ulrey 2008), particularly during poor mast years, its generalist feeding pattern coupled with the availability of multiple alternative foods sympatric with GPW suggest that it may be the lesser beneficiary of the two consumers in this IGM.

The status of the black bear as the only surviving member of the Pleistocene megafauna in Florida strengthens the existing case for bear conservation in the state and areas of the southeastern U.S. coastal plain, as many other species besides the GPW are likely to be dependent on their presence. By increasing abundances of GPW populations, the black bear indirectly enhances the food supply of many other species that consume GPW. For example, GPW have been found in the pellets of burrowing owls (Athene cunicularia 
Molina) (Yosef and Deyrup 1994) and the gizzards of American swallow-tail kites (Elanoides forficatus Linneaus) (Lee and Clark 1993).

Unfortunately, the GPW may become an economically important pest species as a vector of the red ring nematode (Weissling et al. 1992). If so, then some of the other results of this study may prove useful. Abundances within site were linked to temperature but not precipitation, but there is a hint from the variation by a factor of two in trap capture at Smoak ranch between two consecutive years that year-toyear abundance shifts could be large. Longer-term data sets are clearly needed to further evaluate GPW population dynamics and its relationship to climatic patterns at various spatiotemporal scales. Moreover, the strong female bias in trap capture suggests that the traps themselves could provide a way to locally reduce GPW densities where they are problematic.

Our findings indicated that the GPW is a diurnal species, and adults are more active between mid-morning and dusk than between dusk and mid-morning. This suggests that nuisance weevil control using pheromone traps would be most effective if traps were left out during the day when hotter temperatures better volatize weevil attractants. However, we cannot explain why our trap efforts were more successful on cooler days. As such, we encourage further investigation into the relationship between GPW activity and temperature given the economic damage caused by this species and desire to locally control its numbers.

\section{ACKNOWLEDGEMENTS}

We thank Ben Augustine for comments and suggestions on the manuscript. We appreciate the help and support from management at all of the public-access research sites and are particularly grateful for friendship and generosity of the Smoak Family and Archbold Biological Research Station to DSM and his students and colleagues over the years. Experiments were in compliance with natural resource agency and university regulations.

\section{REFERENCES}

Abrahamson, WG, (1999) Episodic reproduction in two fire-prone palms, Serenoa repens and Sabal etonia (Palmae). Ecology, 80, 100-15.

Bare, CO, (1929) Rhynchophorus cruentatus, the palm weevil, attracted to automobile paint. Journal of Economic Entomology, 22, 986.

Blaustein, L, Chase, JM, (2007) Interactions between mosquito larvae and species that share the same trophic level. Annual Review of Entomology, 52, 489-507.

Bodenheimer, FS, (1951) Insects as Human Food, W. Junk, The Hague, The Netherlands.

Brady, JR, Maehr, DS, (1985) Distribution of black bears in Florida. Florida Field Naturalist, 13, 1-7.

Brammer, AS, Crow, WT, (2001) Red Ring Nematode, Bursaphelenchus cocophilus (Cobb) Baujard (Nematoda: Secernentea: Tylenchida: Aphelenchina: Aphelenchoidea: Bursaphelechina) formerly Rhadinaphelenchus cocophilus EENY-236. Nematology Department, Florida Cooperative Extension Service, Institute of Food and Agricultural Sciences, University of Florida, Gainesville.

Bruno, JF, O'Conner, MI, (2005) Cascading effects of predator diversity and omnivory in a marine food web. Ecology Letters, 8, 1048-56.

Bruno, JF, Stachowicz, JJ, Bertness, MD, (2003) Inclusion of facilitation into ecological theory. Trends in Ecology and Evolution, 18, 11925.
Choo, J, Zent EL, Simpson, BB, (2009) The importance of traditional ecological knowledge for palm-weevil cultivation in the Venezuelan Amazon. Journal of Ethnobiology, 29, 113-28.

Crowley, PH, (1992) Resampling methods for computation-intensive data analysis in ecology and evolution. Annual Review of Ecology and Systematics, 23, 405-47.

Crowley, PH, Cox, JJ, (2011) Intraguild mutualism. Trends in Ecology and Evolution, 26, 627-33.

Defoliart, GR, (1995) Edible insects as mini livestock. Biodiversity and Conservation, 4, 306-21.

Dufour, DL, (1987) Insects as food: a case study from the northwest Amazon. American Anthropologist, 89, 383-97.

Florida Fish and Wildlife Conservation Commission, (2010) Draft black bear management plan for Florida, Tallahassee.

Foltz JL, (2001) Coleoptera: Curculionidae. http://web.archive.org/web/201 00829172620/http://entomology.ifas.ufl.edu/foltz/eny3005/lab1/col eoptera/Curculionid.htm Accessed 29 November 2011.

Giblin-Davis, RM, Howard, FW, (1989) Vulnerability of stressed palms to attack by Rhynchophorus cruentatus, (Coleoptera: Curculionidae) and insecticidal control of the pest. Journal of Economic Entomology, 82, 1185-90.

Giblin-Davis, RM, Oehlschlager, AC, Perez, A, Gries, G, Gries, R, Weissling, TJ, Chinchilla, CM Pena, JE, Hallett, RH, Pierce, Jr. HD, Gonzalez, LM, (1996) Chemical and behavioral ecology of palm weevils, (Curculionidae: Rhynchophorinae). Florida Entomologist, 79, 153-67.

Giblin-Davis, RM, Weissling, TJ, Oehlschlager, AC, Gonzalez, LM, (1994) Field response of Rhynchophorus cruentatus (Coleoptera: Curculiondiae) to its aggregation pheromone and fermenting plant volatiles. Florida Entomologist, 77, 164-77.

Gilman, EF, Watson, DG, (1994) Sabal palmetto cabbage palm, Fact Sheet ST-575, Environmental Horticulture Department, Florida Cooperative Extension Service, Institute of Food and Agricultural Sciences, University of Florida, Gainesville.

Godfrey, RK, (1988) Trees, Shrubs, and Woody Vines of Northern Florida and Adjacent Georgia and Alabama, University of Georgia Press, Athens.

Goheen, JR, Swihart, RK, (2003) Food-hoarding behavior of gray squirrels and North American red squirrels in the central hardwoods region: implications for forest regeneration. Canadian Journal of Zoology, $1,1636-9$.

Gómez, JM, Zamora, R, (1994) Top-down effects in a tritrophic system: parasitoids enhance plant fitness. Ecology, 75,1023-30.

Holt, RD, Polis, GA, (1997) A theoretical framework for intraguild predation. The American Naturalist, 149, 745-64.

Hunsberger, AGB, Giblin-Davis, RM, Weissling, TJ, (2000) Symptoms and population dynamics of Rhynchophorus cruentatus (Coleoptera: Curculionidae) in Canary Island date palms. Florida Entomologist, 83, 290-303.

Jacobs, LF, Liman, ER, (1991) Grey squirrels remember the location of buried nuts. Animal Behaviour, 41, 103-10.

Janzen, DH, Martin, PS, (1982) Neotropical anachronisms: The fruit the gomphotheres ate. Science, 215, 19-27.

Lee, DS, Clark, MK, (1993) Notes on post-breeding American swallowtailed kites, Elanoides forficatus (Falconiformes: Accipitridae), in North Central Florida. Brimleyana, 19, 185-203.

Maehr, DS, DeFazio, JT, (1985). Foods of black bears in Florida. Florida Field Naturalist, 13, 8-12.

Maehr, DS, Hoctor, TS, Quinn, LJ, Smith, JS, (2001) Black bear habitat management and guidelines for Florida, Florida Fish and Wildlife Conservation Commission, Technical Report No. 17., Tallahassee, Florida.

Maehr, DS, Layne, JN, (1996) Florida's all purpose plant: the saw palmetto. The Palmetto, Fall.

Manly, BFJ, (1991) Randomization and Monte Carlo Methods in Biology, Chapman \& Hall, London, UK.

McPherson, K, Williams, K, (1998) The role of carbohydrate reserves in the growth, resilience, and persistence of cabbage palm seedlings (Sabal palmetto). Oecologia, 117, 460-8.

Oliveria, JFS, Passos, de Carvalho, SJ, Bruno de Sousa, RFX, Magdalena, SM, (1976) The nutritional value of four species of insects consumed in Angola. Ecology of Food and Nutrition, 5, 91-7.

Oliveria, JFS, Passos, de Carvalho, SJ, Giblin-Davis, RM, Howard, FW, (1989) Vulnerability of stressed palms to attack by Rhynchophorus cruentatus (Coleoptera: Curculionidae) and insecticidal control of the pest. Journal of Economic Entomology, 82, 1185-90. 
Palmer, TM, Stanton, ML, Young, TP, Goheen, JR, Pringle, RM, Karban, $\mathrm{R}$, (2008) Breakdown of an ant-plant mutualism follows the loss of large herbivores from an African savanna. Science, 319, 192-5.

Pimm, SL, Lawton, JH, (1978) On feeding on more than one trophic level. Nature, 275, 542-4.

Rosenheim, JA, (2007) Intraguild predation: New theoretical and empirical perspectives. Ecology, 88, 2679-80.

Sipura, M, (1999) Tritrophic interactions: willows, herbivorous insects and insectivorous birds. Oecologia, 121, 537-45.

Stanton, ML, (2003) Interacting guilds: moving beyond the pairwise perspective on mutualisms. The American Naturalist, 162, S1-S93.

Stevenson, GB, (1996) Palms of South Florida. University Press of Florida, Gainesville, FL, USA.

Tscharntke, T, Hawkins, BA, (2002) Multitrophic level interactions: an introduction, In: Tscharntke T, Hawkins BA, (Eds.) Multitrophic level interactions, Cambridge University Press, Cambridge, UK, 18.

Ulrey, WA, (2008) Home range, habitat use, and food habits of the black bear in south-central Florida. MS thesis, University of Kentucky, Lexington.

Wattanapongsiri, A, (1966) A revision of the genera Rhynchophorus and Dynamis (Coleoptera: Curculionidae). Bangkok Department of Agriculture Science Bulletin 1: 1-328.

Webb, SD, (1974) Pleistocene Mammals of Florida, University Presses of Florida, Gainesville.
Weis, AE, Abrahamson, WG, (1985) Potential selective pressures by parasitoids on a plant-herbivore interaction. Ecology, 66, 1261-9.

Weissling, TJ, Giblin-Davis, RM, Scheffrahn, RH, Mendoza, NM, (1992) Trap for capturing and retaining Rhychophorus cruentatus (Coleoptera: Curculionidae) adults using Sabal palmetto as bait. Florida Entomologist, 75, 212-21.

Weissling, TJ, Giblin-Davis, RM, Scheffrahn, RH, (1993) Laboratory and field evidence for male-produced aggregation pheromone in Rhynchophorus cruentatus (F.) (Coleoptera: Curculionidae). Journal of Chemical Ecology, 19, 1195-203.

Weissling, TJ, Giblin-Davis, RM, (1997) Palmetto weevil. Institute of Food and Agricultural Sciences, University of Florida, Gainesville http:// entnemdept.ifas.ufl.edu/creatures/orn/palmetto_weevil.htm Accessed 10 July 2010.

Weissling, TJ, Giblin-Davis, RM, Gries, G, Gries, R, Perez, AL, Pierce, Jr. HD, Oehlschlager, AC, (1994) Aggregation pheromone of palmetto weevil, Rhynchophorus cruentatus. (F.) (Coleoptera: Curculionidae). Journal of Chemical Ecology, 20, 505-15.

Woodruff, RE, (1967) A giant palm weevil, Rhychophorous cruentatus (Fab.) in Florida (Coleoptera: Curculiondiae). Florida Department of Agriculture, Division of Plant Industry, Entomology Circular No. 63, Tallahassee.

Yosef, R, Deyrup, M, (1994) Pellet analysis of burrowing owls in south central Florida. Florida Field Naturalist, 22, 78-80.

(C) Tedder et al:; Licensee Bentham Open.

This is an open access article licensed under the terms of the Creative Commons Attribution Non-Commercial License (http://creativecommons.org/ licenses/by-nc/3.0/), which permits unrestricted, non-commercial use, distribution and reproduction in any medium, provided the work is properly cited. 